HD

9569. 3

K6K53

1921

NMAH

Kirby

Petroleum Company 


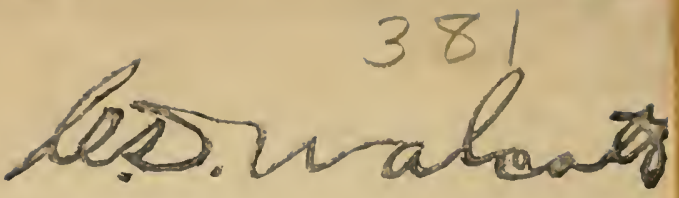

NAAH

\section{Kirby Petroleum Company}

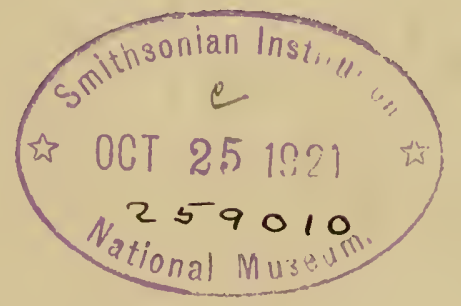


This brochure regarding the personnel of the Directorate of the KIRBY PETROLEUM COMPANY, containing the portraits and biographical sketches of these successful men, is submitted without comment, in the belief that a study of the character of these men, as shown in their portraits and by the record of their achievements, should constitute the best criterion in judging their ability to carefully manage the affairs of any company in which they are vitally interested.

The closing pages contain a number of excerpts from letters received from leading bankers of Houston, Texas, pertaining to the KIRBY PETROLEUM COMPANY in general, and to Mr. John H. Kirby in particular.

We believe it should prove of more than passing interest to present stockholders in the KIRBY PETROLEUM COMPANY, and to those contemplating an investment in its shares.

\section{G. W. MCELHINEY \& CO.}

50 Broad Street,

New York City.

June, 1921. 


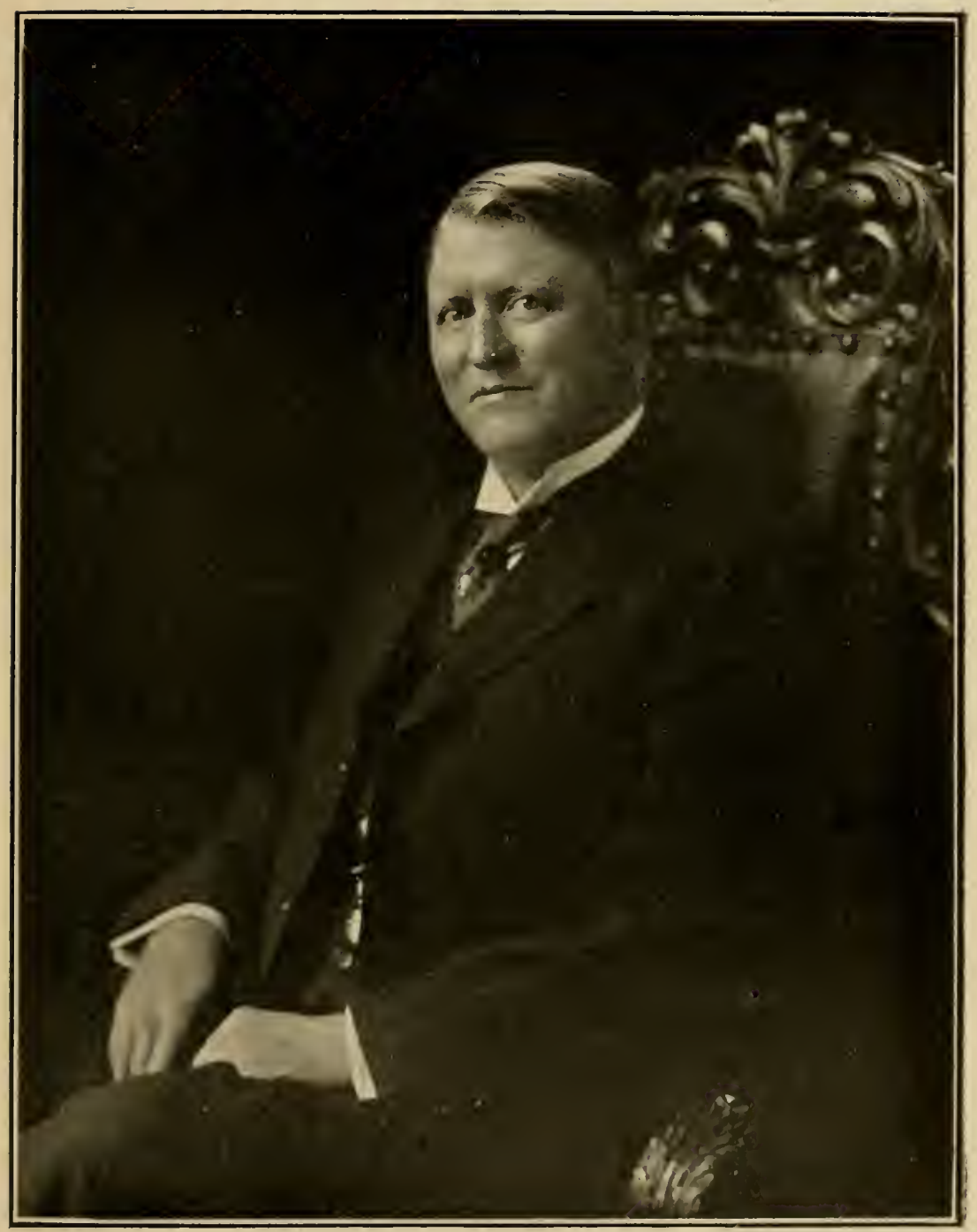

JOHN H. KIRBY

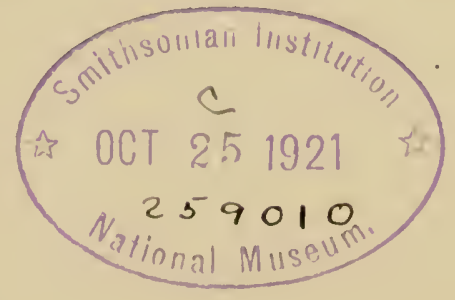



R. JOHN H. KIRBY, President of the Kirby Petroleum Company, was born in the yellow pine timber district of Sontheast Texas in 1860 . He was admitted to the bar of Texas in 1885 .

He has been a leader in the Texas Lumber industry since 1886, in which year he first became interested in pine timber lands in East Texas, and has subsequently deroted nearly all of his time to the upbuilding and development of that great natural resource. Soon after becoming interested in the lumber industry Mr. Kirby gave up the active practice of law in order to devote his full time to the lumber business. He dereloped and managed many successful timber and lumber enterprises.

Mr. Kirby is President of the Kirby Lumber Company, which he organized in 1901, and which is the largest lumber organization erer created in the Southwest. He has successfully held this company in first place for the past twenty years as a manufacturer and distributor of yellow pine lumber. He also is President of the Kirby-Bonner Lumber Company, and of numerous other corporations, and has widely varied interests.

He is universally recognized as a leader in the lumber industry. For the past four years he has been and is President of the National Lumber Manufacturers' Association which represents substantially all of the lumber producing associations in the United States. He was one of the original organizers of the Southern Pine Association, of which he is still a director and Vice-President.

Among his activities in connection with the lumber industry was the building of the Gulf, Beaumont \& Kansas City Railway, a hundred and fifty mile line which is now part of the Atchison, Topeka \& Santa Fe Syrstem.

$\mathrm{He}$ was instrumental in organizing and establishing the Houston Oil Company, one of the largest oil companies in the United States today.

In 1903 Mr. Kirby was President of the Texas World's Fair 
Commission representing the resources of that State at the great Louisiana Furchase Exposition in St. Louis.

In 1904 he was President of the Trans-Mississippi Commercial Congress, one of the greatest developing organizations of the Middle IVest.

He is President of the Southern Tariff Association; one of the Vice-Presidents of the Mississippi Valley Association; and is in fact actively connected with substantially every national organization having to do with the commercial and business activities of the South and Southwest, including the recent $\$ 100,000,000$ finance corporation being presently organized in New York to promote the trade of the United States with foreign countries.

Now, in his 60 th year, while in the full vigor of manhood and mentality, MIr. Kirby seeks to round out this marvelous record with what he is determined to make the crowning achievement of his career, the KIRBY PETROLEUM COMPANY. 


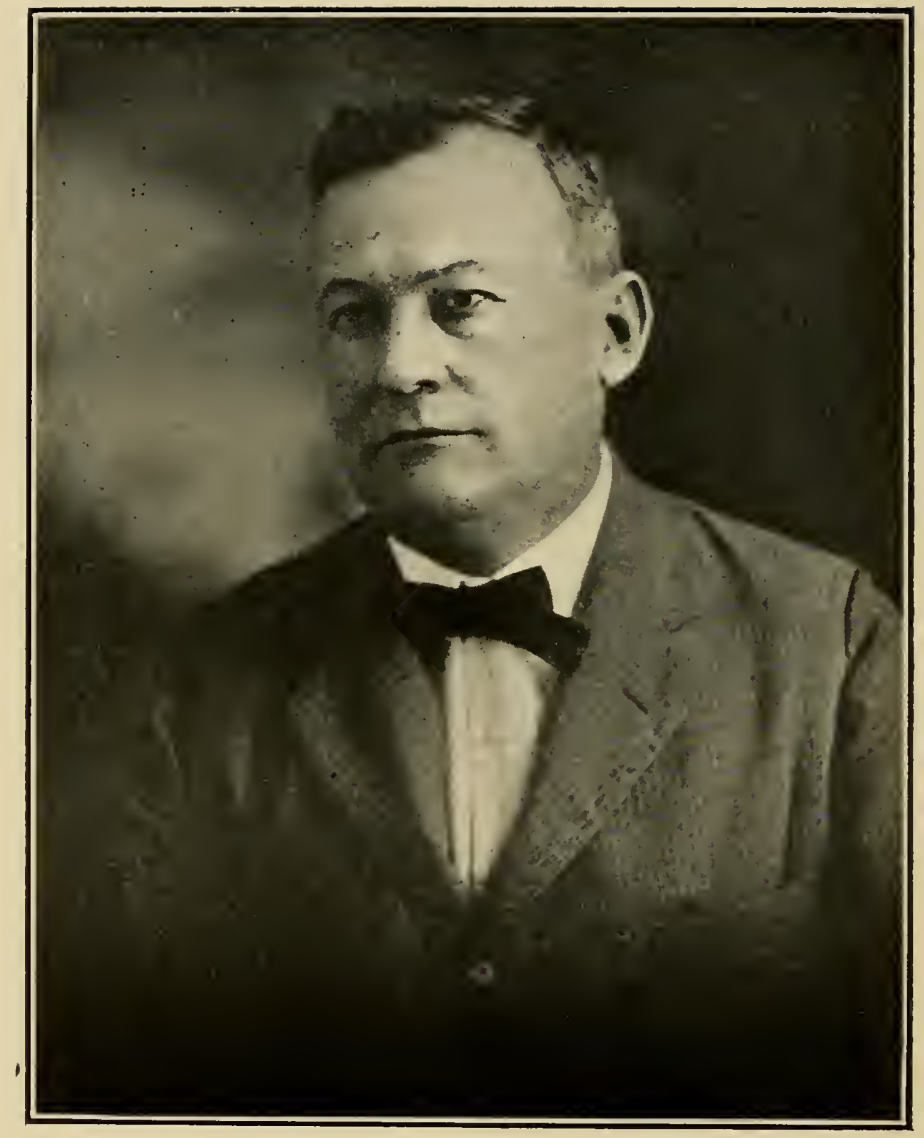

T. II. I $\triangle \wedge$ SS 

R. T. H. BASS, Vice-President and General Manager of the Kirby Petruleum Company, was born in Lec County, Alabama, in the year 1869 . He remosed to the state of Texas in 1886 , where he has made his residence erer since.

He entered the oil producing business at the famous Spindletop oil pool, near Beaumont, Texas, in the year 1900, as superintendent of the Palestine-Beammont Oil Company, which produced under his direction sereral million barrels of oil. The company paid substintial dividends to its stockholders, even at the unprecedented low level of oil prices then prevailing (as low as 5 cents per barrel).

From that beginning to this date, Mr. Bass has devoted his exclusive time to the oil industry-always being identified with field operations-until he is today recognized as one of America's foremost oil operators.

Following his Spindletop operations, he organized the Mary Ellen Oil Company, which operated during the years 1902 to 1904 at the Sour I alke vil pool and the Batson oil pool (Texas). This company paid urer 3,000 per cent in dividends to its shareholders. During part of the same period he was general manager for the Paraffine Oil Company, which paid rery large dividends, and was later merged into the Mumble Oil and Refining Comjany.

In the year 1905 he organized the Evangeline Oil Compan! of Louisiana, which produced, under his direction, sereral million barrels of oil at the Jennings oil pool (Louisiana). 1)uring this connection he built one hundred miles of pipe line from Jennings to Plaquemine, Louisiana, a point on the Mississippi River. This was the first oil pije line ever built in Louisiana, and was a difficult undertaking, as over forty miles of the distance traversed rne of Iondisiana's worst and practically inpregnable swamps, yet it was suceessfully comsummated, and transported millinns of barrels of fucl oil to markets on the Mississippi. This comlany was afterwards absorbed by the Texas Company buying control. 
In 1906 he purchased and owned jointly with J. M. Guffey Petroleum Company of Pittsburgh (now the Gulf Production Company) the Morse lease in the Jennings oil field of Louisiana, and paid very large dividends during that year from these properties, selling his interest later to the Guffey Company.

In 1907 he drilled twenty wells in the celebrated Glenn oil pool near Tulsa, Oklahoma, from which wells large quantities of oil were produced. Later he owned and operated several good oil leases near Morris, Oklahoma, where he played an important part in the bringing in and the proving of the Okmulgee county oil pools (Oklahoma).

From 1907 to 1916 he operated in the various oil fields of the Southwest, including Humble, Spindletop, Sour Lake, Saratoga, Batson and Goose Creek.

Subsequent to 1916 he has been identified with Mr. John H. Kirby in the acquiring, developing and building up of the oil interests now belonging to the Kirby Petroleum Company, and during which period he was among the first to enter the new oil fields in Wichita county (Burkburnett pools and Red River pool); in Brazoria county (West Columbia pool); in Stephens county (Breckenridge pool); and in fact in all recent oil discovery fields in Texas, and has been among the foremost operators in these fields.

Thus, for twenty-one years Mr. Bass has been continually engaged in the practical and operative end of the oil industry, and is especially capable and experienced in the selection, development, and operation of oil properties. Mr. John H. Kirby, President of the Kirby Petroleum Company, unqualifiedly pronounces Mr. Bass--to whom he has entrusted the selection and derelopment of all of the properties now belonging to the Kirby Petroleum Company-one of the best oil operators in America, and Mr. Bass' uniform success is the basis for Mr. Kirby's implicit confidence in his judgment.

Mr. Bass was fifty-two years of age on June 10th of this year, and it would be difficult to find a man more active, or one more intimately conversant with the mid-continent and gulf coast oil fields. 


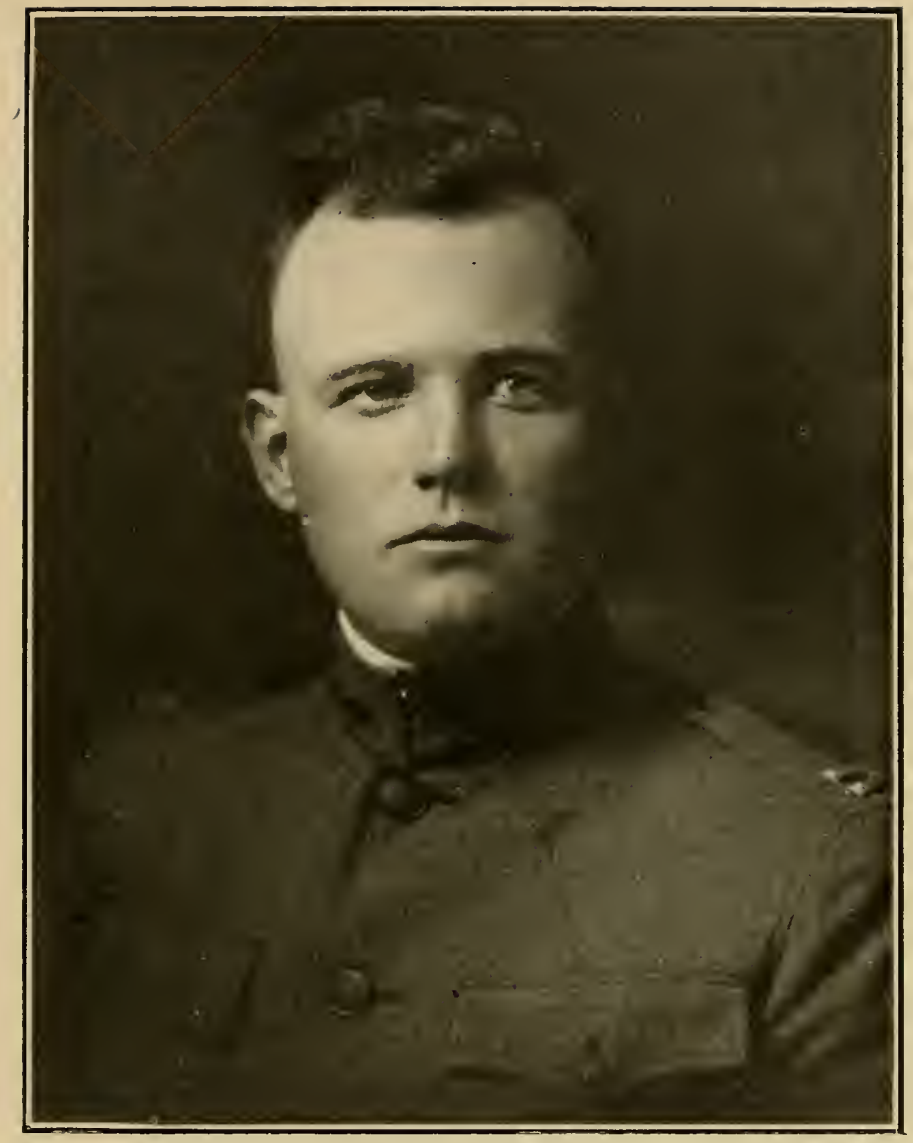

J. G. BASS

W R. J. G. PASS, Director and General Superintendent of the Kirby Petrolcum Company, was born in 1893 and has been a resident of Texas all his life. Following in his father's footsteps (he is the son of Mr. T. H. Bass) he entered the ril producing business as a boy at the age of fourteen, and, while be found time by diligent application to gain his education at the Texas State University, he has been continuously identified in the operating and producing end of the oil industry practically ever since, with the exception of a period of two years during which time he creditably served his country in the great World War as captain of infantry at the front in France. He is now twenty-cight years of age. and his long years of practical experience and exceptinnal ability have eminently qualified him for his present position as general superintendent of the Kirby Petroleum Company's field operations. 


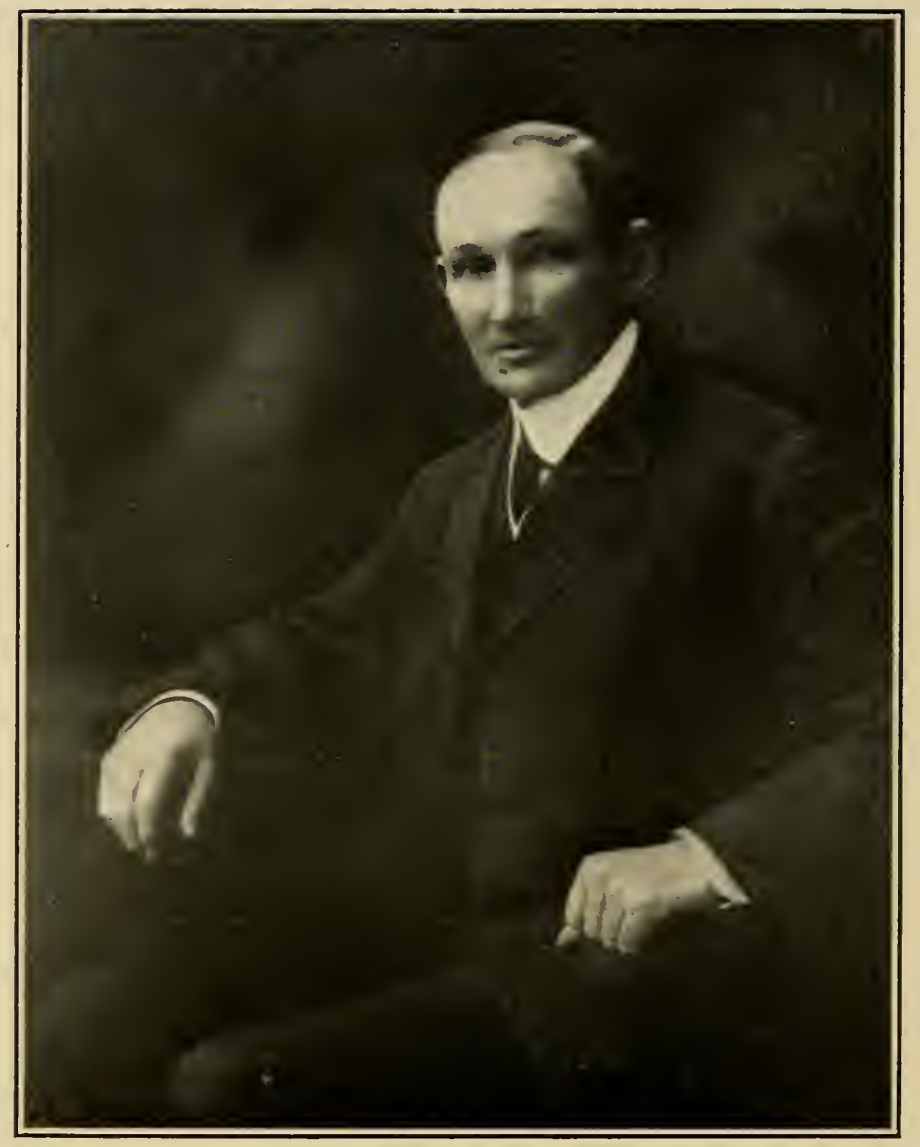

O. S. CARLTON 

R. OSWALD SNIDER CARLTON, Director of the Kirby Petroleum Company, is President of the Great Southern Life Insurance Company of Houston, Texas.

He was born in Alabama on October 25, 1868, and has deroted practically all his life to the business of life insurance. He began his career when but twenty years of age, as agent for the New York Life Insurance Company. He attained conspicuous success in this work, as an agent and as an organizer and directur of men.

After deroting more than twenty years as personal representative and general agent of various companies in Texas and the Southwest, he organized the Great Southern Life Insurance Company, with its home office at Houston, Texas. The company began business in 1909 with a paid-up capital of $\$ 500,000$, and the following statement illustrates its phenomenal growth: On December 31, 1909, the admitted assets were $\$ 602,701.88$, and the insurance in force amounted to $\$ 992,000$ : on December 31, 1920 , the admitted assets were $\$ 10,3+8,509.62$, and the insurance in force amounted to $\$ 105,573,682$.

The success of the Great Southern Life Insurance Company has been a brilliant one, and it is conceded by those familiar with the company and the work of its President, that this success is due to the recognized energy and ability of $\mathbf{M r}$. Carltrn.

He is a big man in insurance and in business circles general1y. His genius for organization and building work is proven by his record in placing and holding his company in the front rank of the insurance business. His talents and experience will be invaluable in the present work of building up and expanding the Kirby l'etroleum Company. 


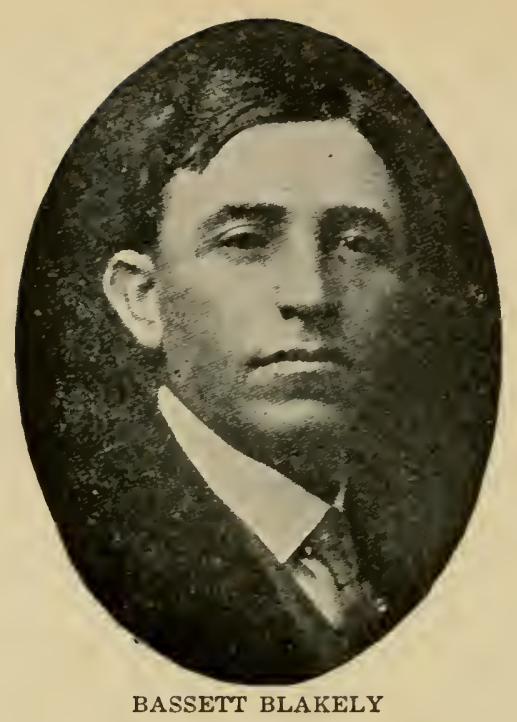

$\prod \begin{aligned} & \text { R. BASSETT BLAKELY, Director of the Kirby Pe- } \\ & \text { troleum Company, was born in Fort Bend County, } \\ & \text { Texas, in 1876, and has lived in Texas ever since. }\end{aligned}$

He was educated in the common schools of Texas, and began his business career by working on a farm for fifteen dollars per month. He then engaged, successively, in:

Keeping a country store; dealing in livestock; planting and ranching; and at the present time owns and deals in valuable tracts of land on a very large scale, and is very wealthy-conservatively rated at more than a million dollars-all the result of his own hard work and ability.

He has been directly and indirectly connected with the Texas oil industry for many years, and has derived a great portion of his wealth therefrom. He owned a very large tract of land, known as the Plue Ridge Plantation (near Houston, Texas), which comprised a great portion of the entire Blue Ridge oil field, and recently sold his oil royalties thereon at very large figures. His financial standing and bank and business credit is of the very highest.

His record has been one of continued advancement by his own efforts, and his business and financial experience is such that his connection adds greatly to the strength of the directorate of the Kirby Petroleum Company, and his services and advice should be invaluable in its present stages of upbuilding and expansion and in its future large operations. 


\section{THE HOUSTON NATIONAL EXCHANGE BANK, HOUSTON, TEXAS.}

June 2nd, 1921.

Messrs. G. W. McElhiney \& Company,

50 Broad Street,

New York City.

\section{Gentlenen :}

Answering your inquiry concerning The Kirby Petroleum Company of this city, I beg to say that I have known the men who are in control of this enterprise for many years. The President, Mr. John H. Kirby, is one of our best known business men. He is one of the pronounced successes of his generation. His reputation for integrity, truth and high character is of the best.

I have likewise known Mr. T. H. Bass, Vice-President and General Manager of the Company, for a great many years, and I have great confidence in his ability as an oil man. He is a good citizen and well known in this section of the country for his integrity, industry and business ability.

Messrs. Blakely and Carlton, Directors, are representative business men of this city, Mr. Carlton, being President of the Great Southern Life Insurance Company, one of the largest life insurance companies in the state, and has been successful from the beginning. Mr. Blakely is a man of large means, being engaged in oil, livestock and farming business.

I know something likewise of the properties of The Kirby Petroleum Company and its business plans, and I have faith in its success.

Very truly yours,

(Signed) Henry S. Fox, JR.,

President. 
What other banks of Houston, Texas, say in recent communications regarding Mr. John H. Kirby

\section{The First National Bank of Houston}

"Mr. John H. Kirby, of the Kirby Lumber Company, is one of the most reputable and substantial business men in Texas. IVe have had long continued dealings with him and have always found him scrupulous and jealous in the performance of his contracts.

"We believe that any statements which Mr. Kirby makes you can be implicitly relied on. He is a man of large means, having been successfully engaged in the lumber business for many years."

\section{The National Bank of Commerce}

"Regarding Mr. John H. Kirby, of this city, will say our understanding is that Mr. Kirby is possessed of very large resources. His personal fortune is said to be several million dollars. $\mathrm{He}$ is a liberal user of credit, and takes good care of his personal obligations.

"Mr. Kirby is largely interesterl in the Kirby Lumber Company, the Kirby-Bonner Lumber Company-which is the selling organization of the Kirby Lumber Company, and recently has organized the Kirby l'etroleum Company, controlled by himself and his close associates. factory."

"Our dealings with him personally have always been satis-

\section{Bankers Mortgage Company}

"Mr. Kirby has been a resident of Houston for a great many years and is one of our very best and highly esteemed citizens and business men. He has been very successful in his business; and his reputation for integrity, truth and high character we consider of the best. We consider him a man of ability and it is our opinion that you can rely upon any statement made by him."

\section{The Lumberman's National Bank}

"Mr. Kirby is very highly regarded locally and considered a man of large means. From what we know of him we do not believe that he would make statements, financially or otherwise, that cruld not be relied on." 


\section{K I R B Y P E T R O LE U M C O M P A N Y}

\section{The Union National Bank}

"Mr. John H. Kirby of the Kirby Lumber Company is regarded as being a man of large means. He is estimated to be worth approximately $\$ 8,000,000.00$ to $\$ 9,000,000.00$. He stands very high locally and throughout the State. WTe regard him as a man of strict honor and integrity."

\section{First Texas Joint Stock Land Bank}

"Mr. Kirby stands very high both morally and financially. He is a man of integrity and wealth. He is in the millionaire class and we consider his paper perfectly good."

\section{South Texas Commercial National Bank}

"Mr. Kirby does not favor us with any business, though we have known him personally for a number of years.

"In a general way, we might say that he has the reputation of being a man of large means and stands well in the business world."

\section{Fidelity Trust Company}

"We have no business relations and no direct means of knowing the present standing of $\mathrm{Mr}$. John H. Kirby of the Kirby Lumber Comprany.

"Dealings in past years with Mr. Kirby were carried out to our entire satisfaction."

\section{Guardian Trust Company}

"Mr. Kirby is considered one of the wealthiest men in Houston. Our business dealings with him have always heen very satisfactory and we regard him as a very able and competent business man." 


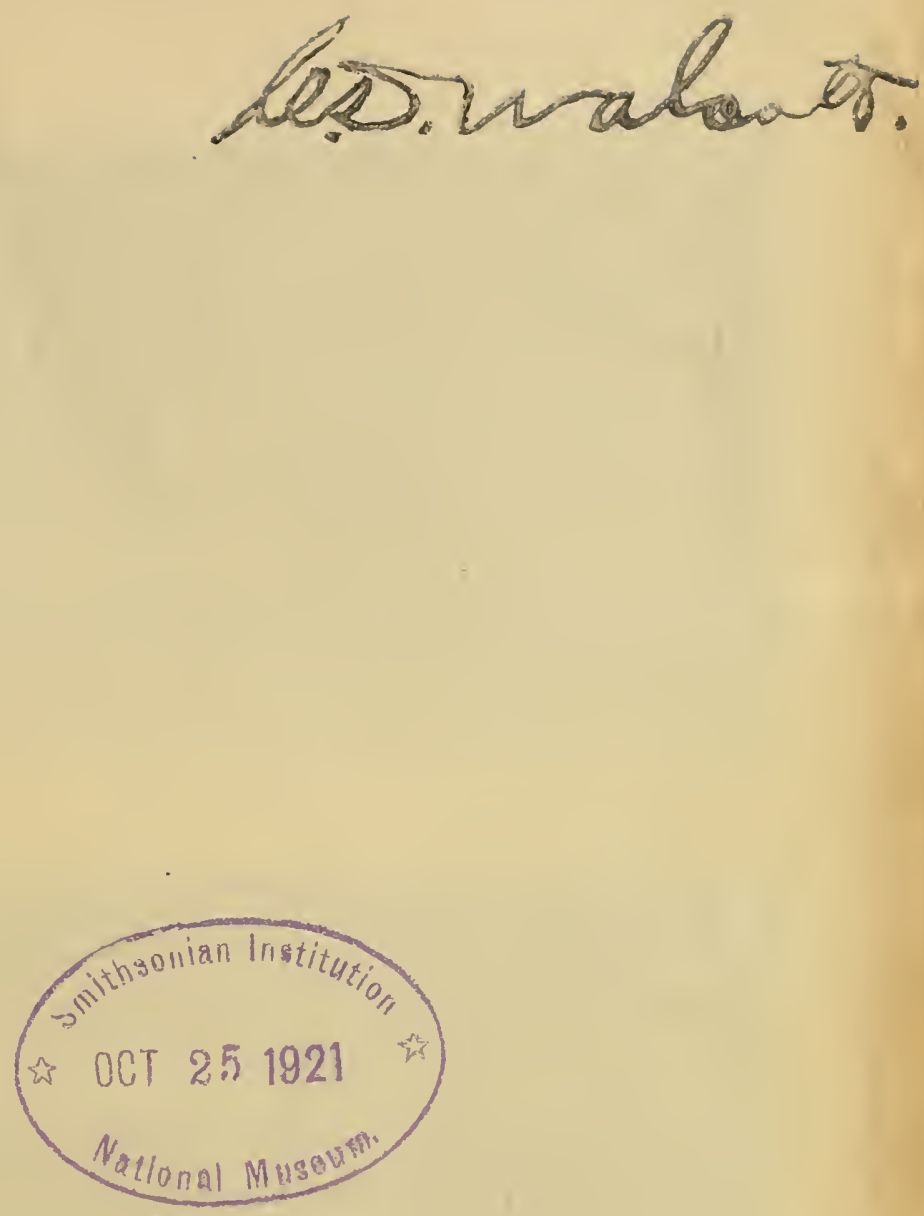



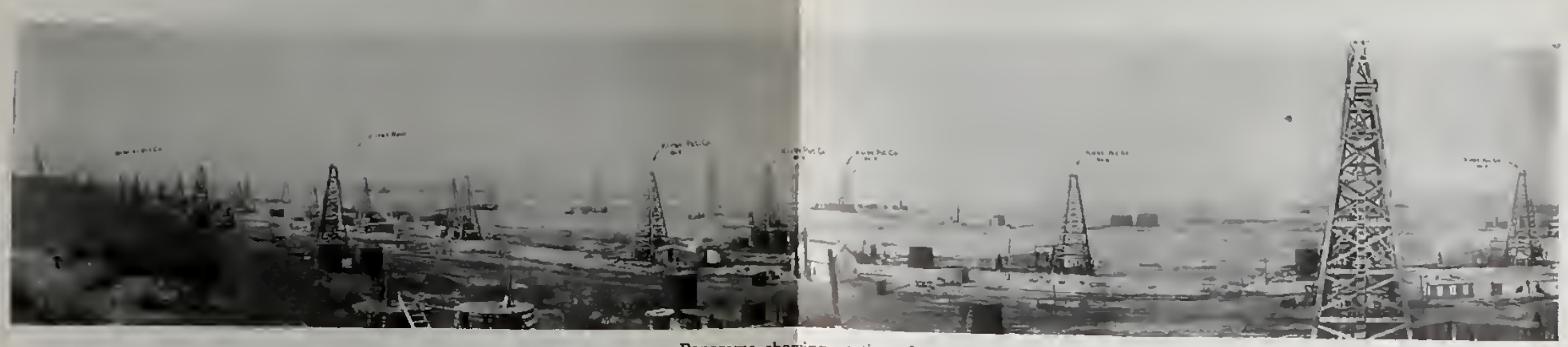

Panorama showing portion of

KIRBY PETROLEUM COMPANY'S
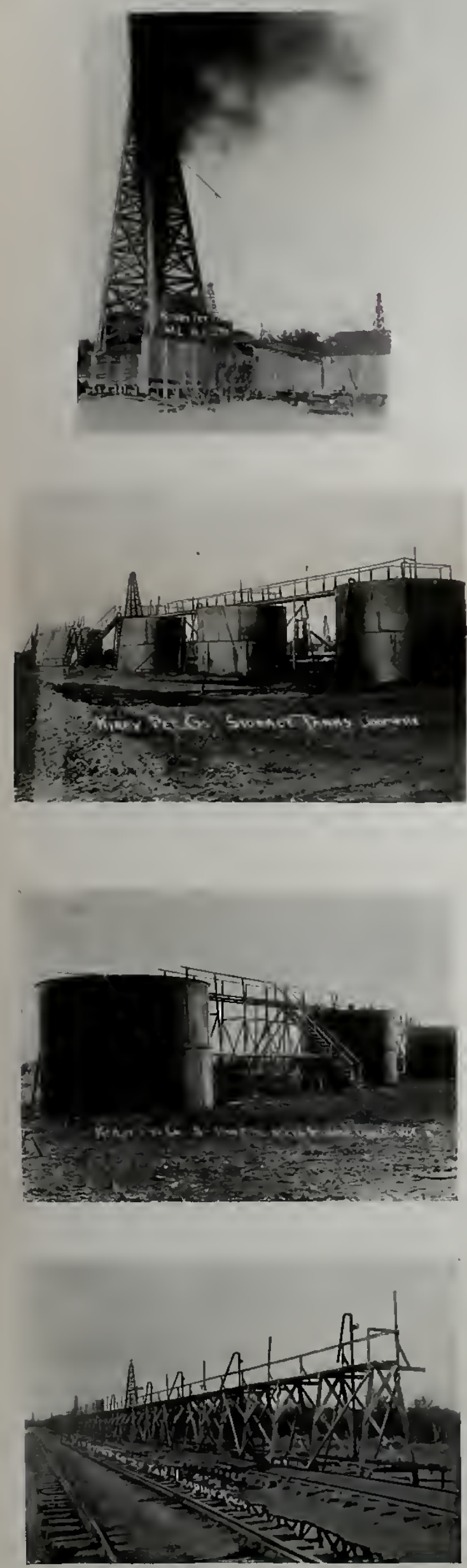

Red River (Wichita County Texas) Holdings and Operations
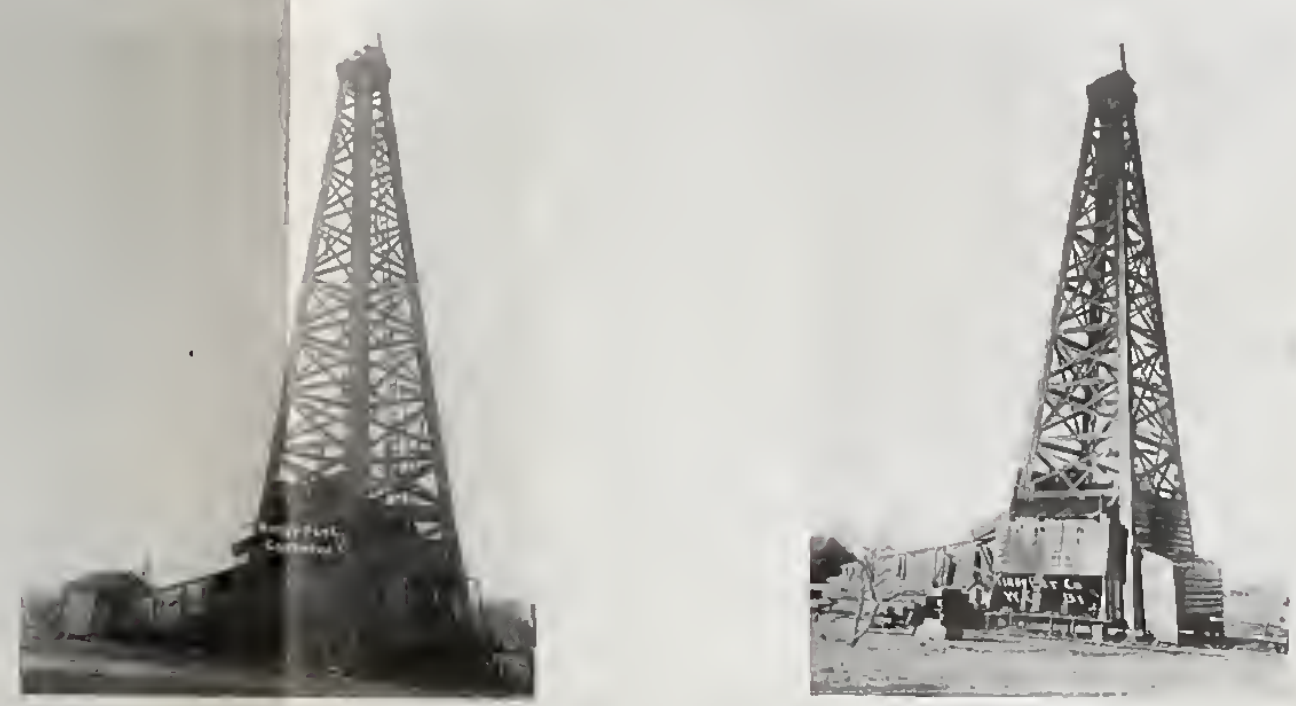

Has produced over $\$ 1,000,000$ since Sept. 15 th, 1920
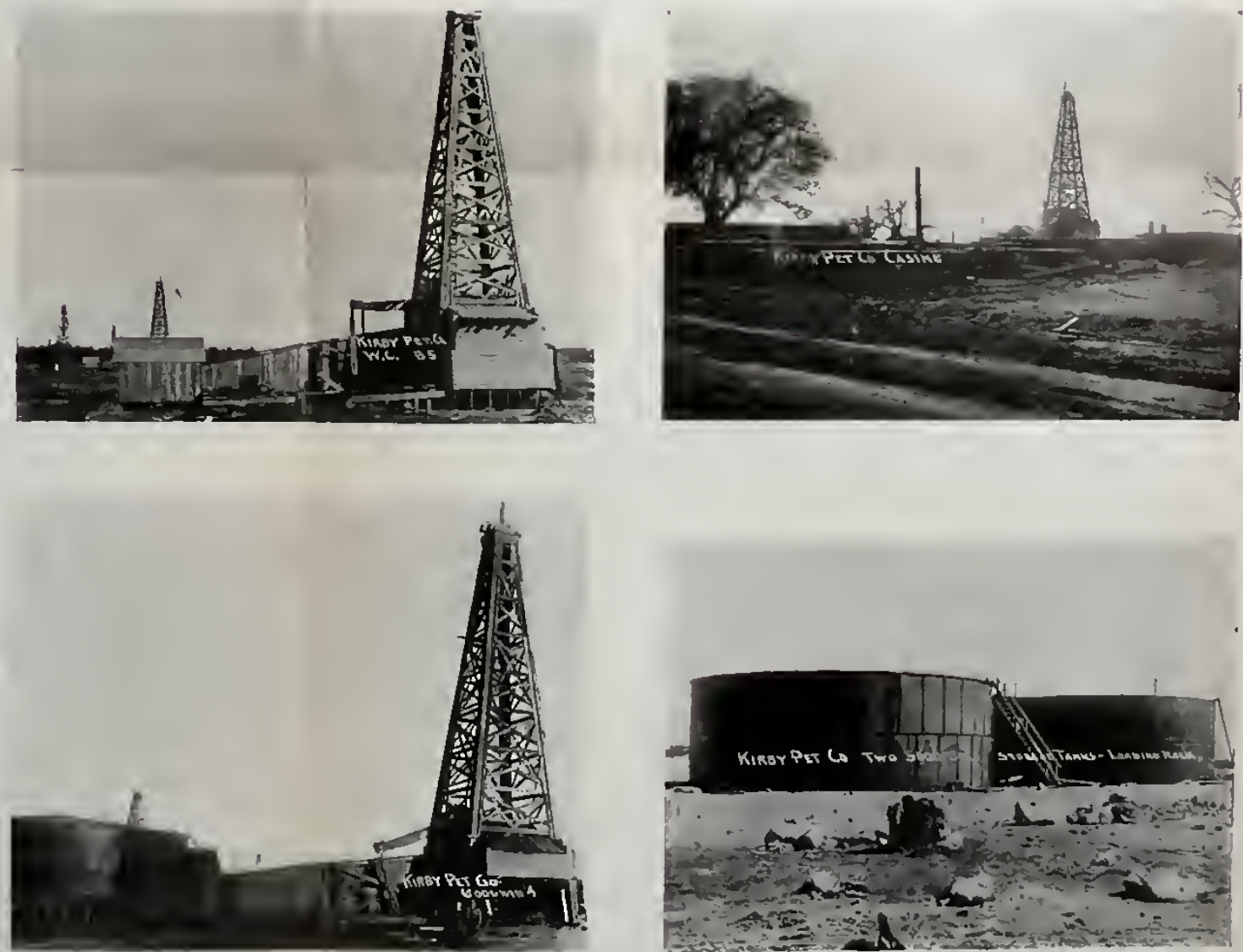

These eleven small photos show some of the operations of the KIRBY PETROLEUM COMPANY in Breckenridge, Texas. (The Company has $\mathrm{I}_{3}$ deep well operations in this field.)

\section{G. W. MCELHINEY \& COMPANY 50 BROAD STREET New York City}

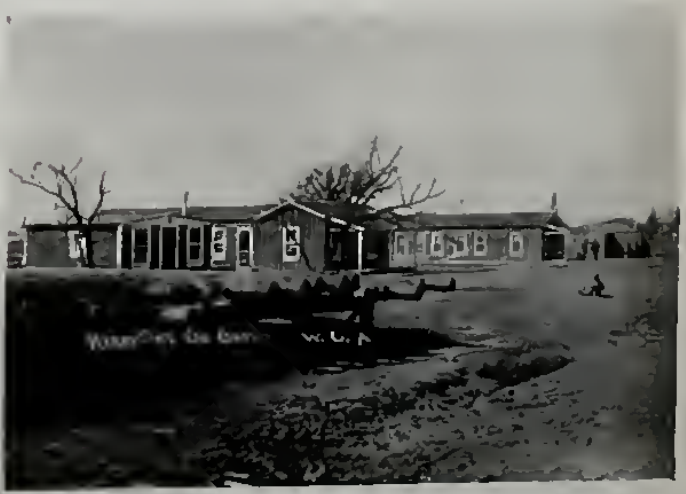



Pressboard

Pamphlet

Binder

Gaylord Bros., Inc.

Syracuse, N. Y.

PAT, IAN. 21, 1908

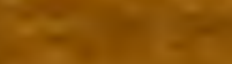


